\title{
Brand image and lexicographic analysis: an application to shopping malls
}

\section{Imagen de marca y análisis lexicográfico: una aplicación a centros comerciales}

\author{
LeONARdo OrTEgón-CORTAZAR ${ }^{1}$ \\ Marcelo Royo Vela ${ }^{2}$ \\ Politécnico Grancolombiano University Institution (Colombia) \\ University of Valencia (Spain)
}

Recibido el 9 de julio de 2014, aceptado el 8 de enero de 2015

$\mathrm{N}^{\mathrm{o}}$ de clasificación JEL: M31, M37

DOI: $10.5295 / \mathrm{cdg} .14048510$

\begin{abstract}
:
The concept of image in its different aspects is very important in today's society as well as in the business management field. Some authors reports that most of the studies that measure "image" do not take into account neither previous theoretical and conceptual models nor other possible empirical evidence alternatives. Given this need, a research regarding the concept of brand image applied to shopping malls was conducted based on the conceptual model of the consumer cognitive response in order to empirically explore and contrast it. For this reason, a survey was applied to 420 consumers in five shopping malls in Bogotá, achieving a database of 3.749 cases. The results show attribute-shopping mall associations expressed in unique, differentiated, and notorious vocabulary obtained applying lexicometric and multivariate analysis techniques. Attribute-shopping mall associations such as "spacious", "good location", "good variety of stores", and the existence of "movie theaters". Finally, this research aims to potentially improve the management of shopping malls and increase their attractiveness and customer loyalty by applying the development of service quality systems, integral communication, segmentation, and positioning.
\end{abstract}

Keywords:

Image, shopping mall, textual data analysis, lexicometric analysis, cognitive response.

\section{Resumen:}

El concepto de imagen en sus diferentes vertientes resulta de gran importancia en la sociedad actual asi como también en el campo de la gestión empresarial. Algunos autores consideran que la mayor parte de los estu-

\footnotetext{
${ }^{1}$ School of Marketing, Communications and Arts, Calle 57 \# 3-00 Este.C.P. 110221, Bogota (Colombia).lortegon@ poligran.edu.co

${ }^{2}$ Department of Commercialization and Market Research, Faculty of Economics, Avda. de los Naranjos s/n. 46022 Valencia (Spain). Marcelo.Royo@uv.es
} 
dios que miden la "imagen", lo hacen sin tener en cuenta modelos conceptuales o teóricos previos de referencia; ni otras posibles alternativas de evidencia empírica. Ante esta circunstancia, se desarrolló una investigación respecto al concepto de imagen de marca aplicada al Centro Comercial tomando como referente el modelo conceptual de la respuesta cognitiva de los consumidores, a fin de explorar y contrastarlo empíricamente. Para tal propósito, se efectuó una encuesta a 420 consumidores en 5 Centros Comerciales en Bogotá logrando configurar una base de datos de 3.749 casos. Los resultados demuestran la existencia de asociaciones atributo - centro comercial, manifestadas en vocabulario único, diferenciado y notorio obtenidas mediante el uso de análisis lexicométrico y técnicas de análisis multivariantes. Asociaciones atributo-centro comercial tales como "amplio", "buena ubicación", "variedad de almacenes", y presencia de "cines". Finalmente la investigación presenta un potencial para mejorar la gestión de los centros comerciales, incrementar su capacidad de atracción y la fidelidad de sus clientes, logrando aplicarse al desarrollo de sistemas de calidad del servicio, comunicación integral, segmentación y posicionamiento.

\section{Palabras Claves:}

Imagen, centro comercial, análisis de datos textuales, análisis lexicométrico, respuesta cognitiva. 


\section{INTRODUCTION}

Image has been widely studied throughout the last decades. From the 50s, the study of image became more important within a new area: marketing (Dobni and Zinkham 1990). As a result, this concept was transferred to branding: a key element to drift away from competitors and, at the same time, achieve better market positioning (Picón et al. 2013 and Martínez et al. 2004).

Brand image, according to Aaker $(1992,1996)$ and Aghekyan-Simonian et al. (2012) is a complex and intuitive construct, which is defined by Keller (1993, p. 3) as: "perceptions about a brand as reflected by the brand associations held in consumer memory." This point of view has been widely accepted and has also been the basis of other definitions for individual or corporate brands (Janonis and Virvilaitè, 2007). Nonetheless, even though brand image has been recognized as a relevant concept in marketing, there is still little agreement on its definition and measurement (Salciuviene et al. 2007).

Likewise, Keller $(1993,2009)$ indicates that brand image is defined not only by its associations, but also by its association quality (positive or negative) in the mind of the consumer, intensity or association strength (high, low, non-existent), and uniqueness (unique association, not shared with other brands.) These three characteristics that make up brand image will guide its conceptualization and measurement in this document.

Cian (2011) recounts that most studies that measure "image" tend to describe it from the models of quality, satisfaction, and service. And that said measurements do not take into account other possible alternatives of empirical evidence. For this reason, it is important to improve and enrich the information analysis methods that are commonly expressed in statements (Winchester and Fletcher 2000). From this point of view, Schmitt (2012) also describes that perceptions and judgments that consumers have about brands are based on the processes that lie under their own management, from the brand's extension worldwide arriving to the concept of value or brand equity. Schmitt expresses that the empirical literature about brands is very extensive and detailed. This has been proven through the literature that exists in this domain. Nevertheless, he also expresses that there is an oversight in the investigation oriented to identify specific empirical findings to facilitate the understanding of how consumers perceive brands (Schmitt 2012).

Human behavior is dependent basically upon reality (image) rather than objective reality (Baloglu and Mccleary 1999, Dobni and Zinkham 1990, Martineau 1958). Levy's classic work (1959) states that people acquire products not only because they are functional, but also because they have a meaning. What consumers perceive is seen as personal and social meanings in addition to function. These meanings -along with their functions- set up the image of a specific product or service. For this reason, the concept of brand image is an essential component of management, differentiation, and mental construction among consumers.

Marketing literature reflects this variety. On the one hand, within the research line of strategic marketing, it has been important to analyze the influence of image on business sales (Aaker 1996, Davis 2002, Ortegón 2012); the effect the positive image of a product has on loyalty towards the brand (Aaker 1996, Bloemer et al. 1998, Robayo and Ortegón 2013); on the already mentioned corporate image (Balmer 2008, Sánchez and Pintado 2009); or on the image of the shopping mall (Hu and Jasper 2006, Varela et al. 2002). 
On the other hand, it is necessary to mention the current research regarding the relationship there is between images in environments other than the organizational. This is the case of product image (Apaolaza and Hartmann 2008, Cretu and Brodie, 2007); tourist destination (Pike, 2002, Varela et al. 2006, Royo 2009); country (Anholt 2007, Moilanen and Rainisto 2009); or the "Made in Effect" or country of origin (Bigné et al. 1993, Montesinos and Currás 2007).

Due to the fact that image can be analyzed, it can also be measured. It is important to differentiate two types of measurement: 1) Service or products are evaluated as a whole (holistic impressions) (Echtner and Ritchie 1991, Pike 2002, Stern et al. 2001, Tapachai and Wariszak 2000) and, 2) Service or products are evaluated based on the attributes or elements that are more outstanding (multi-attribute impressions) (Hong et al. 2006, Macinnis and Price 1987, Martineau 1958, Roth 1995). In any case, Dowling (1986) articulates these image typologies and establishes that "an image is the set of meanings by which an object is known and through which people describe, remember, and relate to it". Along these lines, several authors (Schnittka et al. 2012, Jiménez 2002, Keller 1993, Valls 1992, Villafañe 1993) consider that the set of meanings an object or a brand has can be understood as associations created from the direct experience with the good or service, the information given (by the company, other commercial sources, or by word of mouth), and the inferences resulting from previous knowledge of the company, country of origin, and any other pre-existing association.

Cian (2011) says that given the discussion about the theoretical formulation of brand image, it is logical to expect that its measurement techniques have not been standardized yet. Also, due to the high number of elements that determine brand image, its measurement is not an easy task. One of the motives for this situation is that the perceptions that make up a brand's image are multiple and can refer to tangible and intangible aspects that, additionally, depend on the internal assessment of each individual (Aaker 1994).

Qualitative methods are recognized for allowing the study of brand image, especially to identify benefits or associated attributes (Dolnicar and Grün 2007, Abascal and Grande 1994, Royo 2006, 2009). This identification can also be made by using linguistic coding in addition to the common group dynamics, in-depth interviews, and projection screens.

Winchester and Fletcher (2000) say there are two types of questions used when measuring brand image: free choice and forced choice questions and Driesener and Romaniuk (2006) indicate that the right technique to measure image is the one that classifies descriptive statements in favorable and unfavorable.

This study aims to explore and empirically contrast the image of shopping malls due to its importance in the marketing literature and to the convenience of carrying out empirical studies (McGoldrick and Thompson 1992, Finn and Louviere 1996, Dennis et al. 2000, Molinillo 2002, and Chebat et al. 2010). According to Finn and Louviere (1996), Frasquet (2000), Frasquet et al. (2002), El-Adly (2007), and Chebat et al. (2010) this research is justified by the possible application of the results obtained in order to improve its management in several areas to increase its attraction capacity and its customer's loyalty. This has improved in Colombia (Raddar Consumer Knowledge 2013) and Spain, especially with respect to integrated commercial formats such as networks of branches and franchises (Munuera and Cuestas 2006). This way, the results obtained from the measurement of the image of shopping malls correspond to mere academic and practical interest in order to 
apply them in the development and improvement of service quality systems, management and communication methods, or to propose segmentation and positioning studies (Cian $2011)^{3}$.

\section{METHODOLOGY}

According to Cian (2011), the discussion that exists on the specialized literature regarding the most appropriate type of design and study to investigate about brand image is wide. This shows that there is not a general scale. Based on that and on the cognitive answer of this document, the current investigation used an exploratory design with a semi-structured questionnaire (Guerrero et al. 1999). This design allowed us to obtain qualitative data within the descriptive statements (Winchester and Fletcher 2000) required to have the analysis proposed. In order to measure the brand image of shopping malls, five malls located in Bogotá, Colombia, were taken as reference. Each one of them is a building with a gross leasable area (GLA) of over 1'076.000 square feet, located far from each other, on the five main areas of the city (North, South, East, and West.) Currently, Bogotá has 85 shopping malls (Tourism Observatory of Bogotá, www.bogotamiciudad.com), classified according to ICSC -International Council of Shopping Centers- as follows: 20 shopping malls that correspond to a regional center, 11 are super-regional, 6 are community malls, 5 are thematic, 2 are outlets, and 30 are not classified. As stated in OBS Shopping Malls report (Raddar Consumer Knowledge, 2013), one of the shopping malls studied (Centro Comercial Unicentro) was the best on sales per square foot in 2013, it reached US $\$ 4.580$.

\subsection{Participants}

The answers analyzed correspond to a database of 3.749 cases created from 420 valid questionnaires. The characterization of the sample can be seen in Table 1.

Table 1

Characterization of the Sample

\begin{tabular}{ccc}
\hline \multicolumn{2}{c}{ CLASSIFICATION DATA } & PERCENTAGE \\
\hline Gender & Male & \\
\hline & Female & $54 \%$ \\
\hline Age & & \\
\hline & Minimum & 17 years old \\
\hline & Maximum & 66 years old \\
\hline
\end{tabular}

3 To gather more information regarding the status of the shopping malls and the attraction factors, please refer to Munuera and Cuestas (2006) 


\begin{tabular}{ccc}
\hline & Average & 25 years old \\
\hline Education & & \\
\hline & High School & $25 \%$ \\
\hline Technical & $13 \%$ \\
\hline Technological & $18 \%$ \\
\hline Professional & $37 \%$ \\
\hline & Graduate & $7 \%$ \\
\hline Socioeconomic Level & & \\
\hline & SEL 6 & $50 \%$ \\
\hline & SEL 5 & $13 \%$ \\
\hline SEL 4 & $42 \%$ \\
\hline SEL 3 & $37 \%$ \\
\hline SEL 2 & $2 \%$ \\
\hline
\end{tabular}

Source: Own elaboration.

The participants were selected as long as they expressed knowing all the brands that were studied between June and August, 2013.

\subsection{Instrument}

Regarding the tool used, the literature on this topic indicates that there are diverse measure techniques and scales (Cian 2011). The most common method is the structured questionnaire (Salciuviene et al. 2007, Martínez et al. 2005). An assisted survey was used in order to examine the descriptive statements or the mental associations manifested in the vocabulary linked to each brand (Driesener and Romaniuk 2006). For this reason, we used a semi-structured questionnaire because it is the most convenient method to register mental associations expressed through the oral answers to two questions: a) Favorable or positive idea of the shopping mall and b) Unfavorable or negative idea of the shopping mall. We complemented this with demographic data.

Subsequently, the answers provided by each respondent were analyzed based on the lexicometric approach of qualitative information by using the statistical analysis of vocabulary (Feldman 2002, Satriano and Moscoloni 2000). The analysis technique used was Textual Data Analysis (ADT for its acronym in Spanish) because it enables processing huge volumes of textual information, systematizing answers to open questions, and managing data by preserving the nuance of the language used by the respondents of the sample studied (Barreto et al. 2012). In this case, the vocabulary analyzed belonged to the strengths and weaknesses perceived for each one of the shopping malls (brands.)

The open answers given to these questions were integrated into one variable called verbalization (corpus.) Such variable contained all the lexical forms for the treatment of information oriented to the application of multi-dimensional analysis methods for nominal variables; especially, the study of classification and connections, created from textual data 
according to the qualitative reductionist logic (Feldman 2002, Etxeberría et al. 1995). The main purpose is to connect open answers to the information given in the closed ones or in categorical variables regarding the contextual characteristics of the individuals (Satriano and Moscoloni 2000, Escalas 2004).

\section{RESULTS}

The starting corpus had 11.331 events with 1.026 different forms. Through the elimination of equivalent words or by using nonsense word filtering, it kept $74 \%$ of the information of the starting corpus. This filtering process indicates the process used when studying the verbal behavior of the respondents. A descriptive statistical characterization for the proposed categorical variables was also carried out: type of association, shopping center brands, gender, strata, and education. In general terms, it was possible to observe that the predominating words in the corpus are related to the strengths and to the brand Andino. It was also possible to notice that there was a great number of words related to the following demographic characteristics: consumers under 20 years old, consumers are females, consumers that belong to the middle class (strata 4), and professionals.

When setting up the vocabulary of most used words and segments, we found the following: location, variety, good, stores, low-class people, far away, access, spacious, and food court. The most representative segments were: good location, too far away, bad location, crowded, difficult access, full of people, nice decoration, spacious, bad distribution, very small, and food court.

In order to represent and explain the vocabulary and variable associations named "Type of Association" and "Shopping Center Brand" we applied a factor analysis. Table 2 contains the Eigen values, where Factors 1 and 2 explain $82.5 \%$ of the information presented on the factorial plane.

Table 2

\section{Eigen Values}

\begin{tabular}{cccc}
\hline FACTOR & EIGEN VALUE & $\begin{array}{c}\text { COEFFICIENT OF } \\
\text { DETERMINATION }\end{array}$ & ACCRUED \% \\
\hline 1 & 0,2170 & 65,68 & 65,68 \\
\hline 2 & 0,0556 & 16,82 & 82,50 \\
\hline 3 & 0,0302 & 9,15 & 91,64 \\
\hline 4 & 0,0156 & 4,73 & 96,37 \\
\hline 5 & 0,0120 & 3,63 & 100 \\
\hline
\end{tabular}

Source: Own elaboration. 
Table 3 has the contributions made by interest variables with respect to the factors belonging to each category proposed in the analysis (type of association and shopping center brand.)

Table 3

Contribution and Frequency of Shopping Malls with Respect to Factors 1 and 2

\begin{tabular}{cccc}
\hline \multicolumn{1}{c}{ FREQUENCIES } & & \multicolumn{2}{c}{ CONTRIBUTION } \\
Short Brand & $\begin{array}{c}\text { Relative } \\
\text { Weight }\end{array}$ & Factor 1 & Factor 2 \\
\hline Andino & 10,11 & 0,03 & 52,66 \\
Gran Estación & 10,59 & 0,33 & 0,00 \\
Plaza Américas & 9,44 & 0,47 & 34,99 \\
Portal 80 & 8,57 & 0,03 & 10,28 \\
Unicentro & 11,29 & 0,00 & 1,69 \\
Strengths & 26,14 & 47,31 & 0,18 \\
Weaknesses & 23,86 & 51,82 & 0,19 \\
\hline
\end{tabular}

Source: Own elaboration.

Based on the levels of variety, contribution, and vocabulary explanation, the factorial plane of the textual data analysis was created. The analysis technique performs part of the segmentation and reordering or the units that are present within the texts (Etxeberria et al. 1995), giving lists of word vocabulary and segments. These lists can be used as input of the analysis of correspondences, which describes the proximities between words and allows representing them on factorial planes. According to Becúe (1999), these display the following information: (1) Two words frequently used within the same texts will be closely located in the graphic; (2) in an analogous way, two texts with similar vocabulary will be closer in the graphic. 
Figure 1

\section{Brand Image of Shopping Malls from a Lexicographic Analysis}

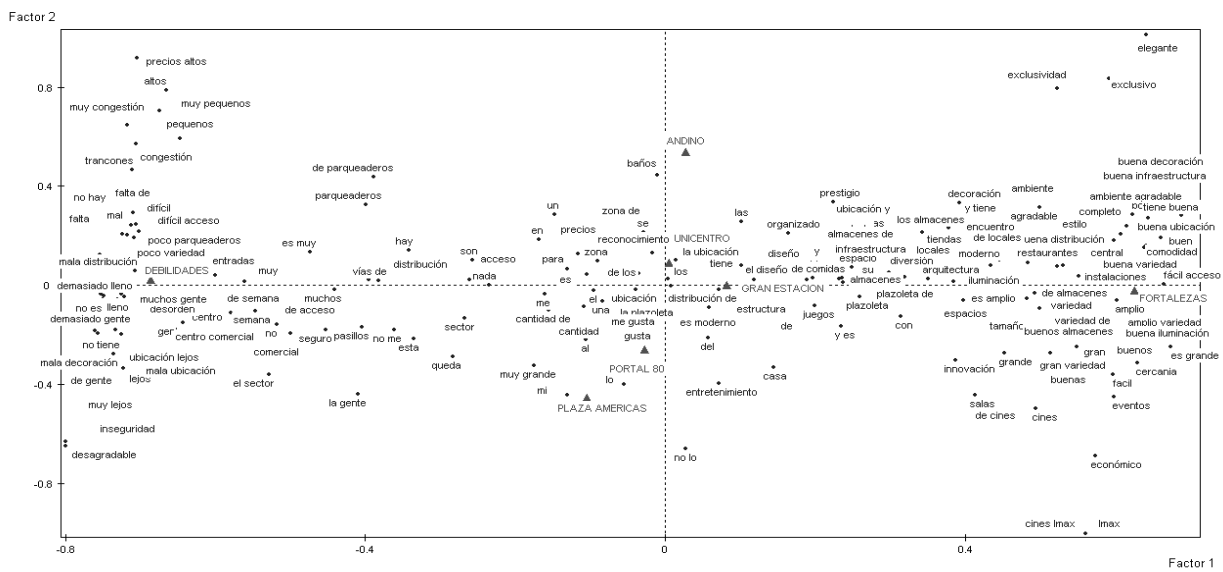

Source: Own elaboration.

Figure 1 shows that Factor 1 is made up by the categories "Strengths" and "Weaknesses" and their information is made by descriptive statements. Factor 2 is built by "upper class" and "low class" categories where brands such as Andino or Plaza de las Américas are tied to exclusivity/prestige and inexpensive, respectively. Figure 2 also indicates that the brand Gran Estación is located in the same quadrant of words related to "strengths" and no brand is located under "weaknesses". At the same time, the brands Portal 80 and Plaza de las Américas are located in the same quadrant, as happens with Unicentro and Andino.

In order to facilitate the lexicographic analysis, specificity tables were created for each categorical variable asked (please refer to Tables 4, 5, 6 and 7). This shows, statistically, the words that are most associated to each category of the plane. The analysis is supported by lexical forms or descriptive statements inferior to probability of error $0.05(\mathrm{p} \leq .05)$. 
Table 4

Specificities of the Variable Shopping Malls

\begin{tabular}{|c|c|c|c|c|c|c|c|}
\hline $\begin{array}{l}\text { Shopping } \\
\text { Malls }\end{array}$ & $\begin{array}{l}\text { Characteristic } \\
\text { Words or Seg- } \\
\text { ments }\end{array}$ & $\begin{array}{c}\text { Internal } \\
\text { Percentage }\end{array}$ & $\begin{array}{l}\text { Global } \\
\text { Percent- } \\
\text { age }\end{array}$ & $\begin{array}{l}\text { Internal } \\
\text { Fre- } \\
\text { quency }\end{array}$ & $\begin{array}{l}\text { Global } \\
\text { Fre- } \\
\text { quency }\end{array}$ & $\begin{array}{c}\text { Test } \\
\text { Value }\end{array}$ & $\begin{array}{l}\text { Proba- } \\
\text { bility* }\end{array}$ \\
\hline \multirow{6}{*}{ Andino } & $\begin{array}{l}\text { Crowded (Ag- } \\
\text { glomeration) }\end{array}$ & 4,96 & 2 & 98 & 191 & 9,393 & 0,001 \\
\hline & Elegant & 1,06 & 0,24 & 21 & 23 & 7,095 & 0,001 \\
\hline & Exclusive & 1,06 & 0,28 & 21 & 27 & 6,182 & 0,001 \\
\hline & Decoration & 2,28 & 1,11 & 45 & 106 & 5,001 & 0,001 \\
\hline & Expensive & 0,71 & 0,2 & 14 & 19 & 4,735 & 0,001 \\
\hline & Prestige & 0,76 & 0,36 & 15 & 34 & 2,923 & 0,002 \\
\hline \multirow{5}{*}{$\begin{array}{c}\text { Gran } \\
\text { Estación }\end{array}$} & Design & 1,58 & 0,89 & 32 & 85 & 3,37 & 0,001 \\
\hline & Spacious & 3,11 & 2,09 & 63 & 200 & 3,359 & 0,001 \\
\hline & Inexpensive & 0,15 & 0,7 & 3 & 67 & $-3,668$ & 0,001 \\
\hline & $\begin{array}{l}\text { Bad Distribu- } \\
\text { tion }\end{array}$ & 0,84 & 0,4 & 17 & 38 & 3,085 & 0,001 \\
\hline & Large & 1,92 & 1,2 & 39 & 115 & 3,077 & 0,001 \\
\hline \multirow{6}{*}{$\begin{array}{c}\text { Plaza } \\
\text { Américas }\end{array}$} & Insecurity & 1,11 & 0,41 & 20 & 39 & 4,41 & 0,001 \\
\hline & Inexpensive & 1,55 & 0,7 & 28 & 67 & 4,224 & 0,001 \\
\hline & Innovation & 1,05 & 0,41 & 19 & 39 & 4,076 & 0,001 \\
\hline & Crowded & 0,94 & 2 & 17 & 191 & $-3,748$ & 0,001 \\
\hline & Bad Location & 1,72 & 1,02 & 31 & 97 & 2,958 & 0,002 \\
\hline & $\begin{array}{l}\text { Food Court } \\
\text { (Restaurants) }\end{array}$ & 0,61 & 1,28 & 11 & 122 & $-2,852$ & 0,002 \\
\hline \multirow{6}{*}{ Portal 80} & Movie Theaters & 4,29 & 1,9 & 71 & 181 & 6,97 & 0,001 \\
\hline & Inexpensive & 2 & 0,7 & 33 & 67 & 5,903 & 0,001 \\
\hline & $\begin{array}{l}\text { Parking Space } \\
\text { (Parking Lots) }\end{array}$ & 0,54 & 1,74 & 9 & 166 & $-4,482$ & 0,001 \\
\hline & Crowded & 0,42 & 2 & 7 & 191 & $-5,748$ & 0,001 \\
\hline & Insecurity & 0,85 & 0,41 & 14 & 39 & 2,636 & 0,004 \\
\hline & Nice Stores & 0,42 & 0,17 & 7 & 16 & 2,24 & 0,013 \\
\hline \multirow{6}{*}{ Unicentro } & Parking Space & 2,92 & 1,74 & 61 & 166 & 4,326 & 0,001 \\
\hline & $\begin{array}{l}\text { Variety of } \\
\text { Stores }\end{array}$ & 3,26 & 2,05 & 68 & 196 & 3,994 & 0,001 \\
\hline & Difficult Access & 1,2 & 0,61 & 25 & 58 & 3,475 & 0,001 \\
\hline & Spacious & 0,86 & 0,4 & 18 & 38 & 3,316 & 0,001 \\
\hline & Very Crowded & 1,01 & 0,56 & 21 & 53 & 2,777 & 0,003 \\
\hline & Innovation & 0,14 & 0,41 & 3 & 39 & $-2,104$ & 0,018 \\
\hline
\end{tabular}

*Only words with probability inferior to 0.05 are included.

Source: Own elaboration. 
Table 4 shows the vocabulary of words and segments that characterize each shopping mall. In order to enhance the analysis of vocabulary and characteristic profile, Tables 5 and 6 show the meaningful associations of vocabulary with other variables -such as demographic characteristics- (El-Adly 2007).

Table 5

\section{Specificities of the Variable Type of Association}

\begin{tabular}{|c|c|c|c|c|c|c|c|}
\hline Attribute & $\begin{array}{c}\text { Characteristic } \\
\text { Words or } \\
\text { Segments }\end{array}$ & $\begin{array}{c}\text { Internal } \\
\text { Percen- } \\
\text { tage }\end{array}$ & $\begin{array}{l}\text { Global } \\
\text { Percen- } \\
\text { tage }\end{array}$ & $\begin{array}{c}\text { Internal } \\
\text { Fre- } \\
\text { quency }\end{array}$ & $\begin{array}{c}\text { Global } \\
\text { Frequen- } \\
\text { cy }\end{array}$ & $\begin{array}{c}\text { Test } \\
\text { Value }\end{array}$ & $\begin{array}{l}\text { Proba- } \\
\text { bility* }\end{array}$ \\
\hline \multirow[t]{11}{*}{ Strengths } & Spacious & 3,71 & 2,09 & 188 & 200 & 12,864 & 0,001 \\
\hline & $\begin{array}{l}\text { Good Loca- } \\
\text { tion }\end{array}$ & 2,27 & 1,20 & 115 & 115 & 11,738 & 0,001 \\
\hline & $\begin{array}{l}\text { Movie Thea- } \\
\text { ters }\end{array}$ & 3,22 & 1,90 & 163 & 181 & 10,774 & 0,001 \\
\hline & Variety & 3,43 & 2,05 & 174 & 196 & 10,577 & 0,001 \\
\hline & Inexpensive & 1,28 & 0,70 & 65 & 67 & 8,015 & 0,001 \\
\hline & Stores & 4,60 & 3,27 & 233 & 312 & 7,905 & 0,001 \\
\hline & Closeness & 1,10 & 0,60 & 56 & 57 & 7,662 & 0,001 \\
\hline & $\begin{array}{l}\text { Well-deco- } \\
\text { rated }\end{array}$ & 1,01 & 0,54 & 51 & 52 & 7,222 & 0,001 \\
\hline & Large & 1,91 & 1,20 & 97 & 115 & 7,013 & 0,001 \\
\hline & Nice & 1,20 & 0,70 & 61 & 67 & 6,625 & 0,001 \\
\hline & Crowded & & & & & & \\
\hline \multirow[t]{9}{*}{ Weaknesses } & $\begin{array}{l}\text { (Agglomera- } \\
\text { tion) }\end{array}$ & 4,22 & 2,00 & 189 & 191 & 16,308 & 0,001 \\
\hline & Too far & 2,19 & 1,04 & 98 & 99 & 11,518 & 0,001 \\
\hline & Bad Location & 2,14 & 1,02 & 96 & 97 & 11,391 & 0,001 \\
\hline & $\begin{array}{l}\text { Very Crowd- } \\
\text { ed }\end{array}$ & 1,92 & 0,90 & 86 & 86 & 11,083 & 0,001 \\
\hline & $\begin{array}{l}\text { Difficult } \\
\text { Access }\end{array}$ & 1,27 & 0,61 & 57 & 58 & 8,542 & 0,001 \\
\hline & $\begin{array}{l}\text { Parking Space } \\
\text { (Parking } \\
\text { Lots) }\end{array}$ & 2,86 & 1,74 & 128 & 166 & 7,938 & 0,001 \\
\hline & Messy & 0,96 & 0,45 & 43 & 43 & 7,705 & 0,001 \\
\hline & Insecurity & 0,87 & 0,41 & 39 & 39 & 7,306 & 0,001 \\
\hline & $\begin{array}{l}\text { Bad Distribu- } \\
\text { tion }\end{array}$ & 0,85 & 0,40 & 38 & 38 & 7,180 & 0,001 \\
\hline
\end{tabular}

*Only words with probability inferior to 0.05 are included.

Source: Own elaboration. 
Table 6

Specificities of the Variable Gender

\begin{tabular}{|c|c|c|c|c|c|c|c|}
\hline Gender & $\begin{array}{l}\text { Characteris- } \\
\text { tic Words or } \\
\text { Segments }\end{array}$ & $\begin{array}{c}\text { Internal } \\
\text { Percentage }\end{array}$ & $\begin{array}{l}\text { Global } \\
\text { Percen- } \\
\text { tage }\end{array}$ & $\begin{array}{l}\text { Internal } \\
\text { Fre- } \\
\text { quency }\end{array}$ & $\begin{array}{c}\text { Global } \\
\text { Frequency }\end{array}$ & $\begin{array}{c}\text { Test } \\
\text { Value }\end{array}$ & Probability* \\
\hline \multirow[t]{7}{*}{ Male } & Spacious & 2,69 & 2,11 & 108 & 200 & 3,258 & 0,001 \\
\hline & $\begin{array}{l}\text { Parking Space } \\
\text { (Parking Lots) }\end{array}$ & 2,24 & 1,75 & 90 & 166 & 3,006 & 0,001 \\
\hline & $\begin{array}{l}\text { Difficult } \\
\text { Access }\end{array}$ & 0,9 & 0,61 & 36 & 58 & 2,868 & 0,002 \\
\hline & Stores & 2,71 & 3,29 & 109 & 312 & $-2,681$ & 0,004 \\
\hline & Design & 1,17 & 0,9 & 47 & 85 & 2,29 & 0,011 \\
\hline & Central & 0,12 & 0,26 & 5 & 25 & $-2,131$ & 0,017 \\
\hline & $\begin{array}{l}\text { Very Crowded } \\
\text { (Agglomera- } \\
\text { tion) }\end{array}$ & 0,07 & 0,19 & 3 & 18 & $-2,041$ & 0,021 \\
\hline \multirow[t]{8}{*}{ Female } & Stores & 1,72 & 1,43 & 94 & 135 & 2.766 & 0,003 \\
\hline & Beautiful & 0,59 & 0,43 & 32 & 41 & 2,575 & 0,005 \\
\hline & Large & 1,47 & 1,21 & 80 & 115 & 2,557 & 0,005 \\
\hline & $\begin{array}{c}\text { Nice Environ- } \\
\text { ment }\end{array}$ & 0,13 & 0,24 & 7 & 23 & $-2,411$ & 0,008 \\
\hline & Variety & 2,35 & 2,07 & 128 & 196 & 2,108 & 0,018 \\
\hline & $\begin{array}{l}\text { Very Crowded } \\
\text { (Agglomera- } \\
\text { tion) }\end{array}$ & 0,28 & 0,19 & 15 & 18 & 2,041 & 0,021 \\
\hline & Brands & 0,39 & 0,29 & 21 & 27 & 1,979 & 0,024 \\
\hline & Restaurants & 0,35 & 0,26 & 19 & 25 & 1,693 & 0,045 \\
\hline
\end{tabular}

*Only words with probability inferior to 0.05 are included.

Source: Own elaboration. 
Table 7

Specificities of the Variable Socioeconomic Level

\begin{tabular}{|c|c|c|c|c|c|c|c|}
\hline Attribute & $\begin{array}{c}\text { Characteristic } \\
\text { Words or } \\
\text { Segments }\end{array}$ & $\begin{array}{c}\text { Internal } \\
\text { Percent- } \\
\text { age }\end{array}$ & $\begin{array}{l}\text { Global } \\
\text { Percent- } \\
\text { age }\end{array}$ & $\begin{array}{c}\text { Internal } \\
\text { Fre- } \\
\text { quency }\end{array}$ & $\begin{array}{l}\text { Global } \\
\text { Frequen- } \\
\text { cy }\end{array}$ & $\begin{array}{c}\text { Test } \\
\text { Value }\end{array}$ & Probability* \\
\hline \multirow[t]{4}{*}{ SEL 2} & Stores & 8,41 & 3,29 & 18 & 312 & 3,489 & 0,001 \\
\hline & Organized & 1,40 & 0,17 & 3 & 16 & 2,568 & 0,005 \\
\hline & Variety & 4,21 & 2,07 & 9 & 196 & 1,779 & 0,038 \\
\hline & Food Court & 3,27 & 1,49 & 7 & 141 & 1,745 & 0,041 \\
\hline \multirow[t]{5}{*}{ SEL 3} & Arcade & 0,4 & 0,19 & 14 & 18 & 3,334 & 0,001 \\
\hline & Spacious & 0,12 & 0,4 & 4 & 38 & $-3,409$ & 0,001 \\
\hline & $\begin{array}{l}\text { Nice Decora- } \\
\text { tion }\end{array}$ & 0,17 & 0,55 & 6 & 52 & $-3,872$ & 0,001 \\
\hline & Modern & 0,12 & 0,53 & 4 & 50 & $-4,474$ & 0,001 \\
\hline & Stores & 0,61 & 0,35 & 21 & 33 & 2,996 & 0,001 \\
\hline \multirow[t]{6}{*}{ SEL 4} & Variety & 1,47 & 2,07 & 59 & 196 & $-3,448$ & 0,001 \\
\hline & Stores & 0,92 & 1,42 & 37 & 135 & $-3,501$ & 0,001 \\
\hline & Distribution & 1,24 & 0,88 & 50 & 83 & 3,16 & 0,001 \\
\hline & Location & 6,66 & 5,78 & 268 & 548 & 3,09 & 0,001 \\
\hline & Spacious & 0,57 & 0,4 & 23 & 38 & 2,073 & 0,019 \\
\hline & $\begin{array}{l}\text { Well-deco- } \\
\text { rated }\end{array}$ & 0,75 & 0,55 & 30 & 52 & 2,064 & 0,019 \\
\hline \multirow[t]{7}{*}{ SEL 5} & Modern & 1,39 & 0,53 & 18 & 50 & 3,843 & 0,000 \\
\hline & Stores & 2,39 & 1,42 & 31 & 135 & 2,787 & 0,003 \\
\hline & $\begin{array}{l}\text { Well-deco- } \\
\text { rated }\end{array}$ & 1,15 & 0,55 & 15 & 52 & 2,699 & 0,003 \\
\hline & $\begin{array}{l}\text { Bad Distribu- } \\
\text { tion }\end{array}$ & 0 & 0,4 & 0 & 38 & $-2,676$ & 0,004 \\
\hline & Prestige & 0,77 & 0,36 & 10 & 34 & 2,221 & 0,013 \\
\hline & Access & 0 & 0,28 & 0 & 27 & $-2,08$ & 0,019 \\
\hline & Entertaining & 0,38 & 0,16 & 5 & 15 & 1,705 & 0,044 \\
\hline & $\begin{array}{l}\text { Very Crowd- } \\
\text { ed (Agglom- } \\
\text { eration) }\end{array}$ & 1,73 & 0,56 & 8 & 53 & 2,64 & 0,004 \\
\hline \multirow{3}{*}{ SEL 6} & Premises & 1,95 & 0,76 & 9 & 72 & 2,409 & 0,008 \\
\hline & Location & 8,44 & 5,78 & 39 & 548 & 2,299 & 0,011 \\
\hline & Large & 0,22 & 1,21 & 1 & 115 & $-2,028$ & 0,021 \\
\hline
\end{tabular}




$\begin{array}{ccccccc}\text { Variety } & 2,38 & 4,24 & 11 & 402 & -2,029 & 0,021 \\ \text { Location } & 0,87 & 0,25 & 4 & 24 & 1,913 & 0,028 \\ \begin{array}{c}\text { Few Parking } \\ \text { Lots }\end{array} & 0,65 & 0,17 & 3 & 16 & 1,743 & 0,041\end{array}$

*Only words with probability inferior to 0.05 are included.

Source: Own elaboration.

In summary, it was possible to observe that the brand image of the shopping mall Andino received descriptions such as: crowded (agglomeration), elegant, exclusive and prestigious, well-decorated, and expensive. The brand image of the shopping mall Gran Estación is described as: large, inexpensive, and crowded. The brand image of the shopping mall Plaza de las Américas is described as: innovative, dangerous areas, inexpensive, social, with many restaurants and fast food restaurants (food courts). The brand image of the shopping mall Portal 80 is described as: movie theaters, inexpensive, and parking space; and the brand image of the shopping mall Unicentro is described as: variety of stores, spacious, and innovative.

\section{DISCUSSION}

It was possible to demonstrate that exploration and investigation on brand image are vital elements for companies that participate in competitive markets (Simms and Trott 2006, Picón et al. 2013). Likewise, some studies have shown that brand image provides consumers with great deals of information regarding quality, value, personality, as well as the benefits related to consumerism (Aaker and Keller 1990, 1996, Keller 1993, 2003, Simms and Trott 2006, Cian 2011, Schmitt 2012). According to this, the analyses used to explore the associations constituting brand image provide results that can inform decisions regarding business or marketing strategies based on a better understanding of the attributes that help identifying a brand; the different types of associations linked to one or several brands; the level of favorability and uniqueness (differentiation) per types of segment where a brand acts; and the level of association strength regarding the performance of a brand.

The design and the findings allowed relating to the academic research opportunities described by Schmitt (2012) regarding the identification of empirical findings that enable understanding how consumers perceive brands, and by Cian (2011) with respect to the measurement of this construct according to the theory proposed.

From an applied perspective, this research goes along the lines with some of the reasons suggested by the MSI (Marketing Science Institute) to study brands and develop brand equity: (1) To lead marketing strategies to tactical decisions, (2) To evaluate the effectiveness of the decisions made regarding the management of recognition attributes (from marketing), and (3) To increase the status of the brand with respect to its competitors (De la Martinièr et al. 2008, p. 22). Even though it is true that this research does not describe a construction process of applied brand image, it does provide information that could, potentially, guide on these purposes. 
The information analysis carried out with the proposed technique is consistent with the cognitive conceptual body of the consumer because associations are expressed not only by the vocabulary used for each brand, but also by the qualifications used to evaluate the brands according to the attributes proposed. At the same time, this type of research has been examined and measured per vocabulary or descriptive statements over the last few years, according to Winchester and Fletcher (2000). Likewise, this study has shown how the techniques used, especially the lexicographic analysis, provide with an alternative measurement of brand image associations by examining their variety, wealth, strength, uniqueness, and differentiation.

The results obtained from the mental associations confirmed the theoretical revision with respect to the idea that associations are the product of previous experience and/or come from sources not controllable by the consumer, such as third party references, massive media, and even the inference of associations based on previously existing ones; for example, verbal associations around: "insecurity", "too much traffic", "too far" (Valls 1992, Keller 1993, Villafañe 1993, Jiménez 2002, Janonis and Virvilaitė 2007).

In conclusion, and based on the previous arguments, this study contributes as follows:

(1) To increasing the strategic knowledge of brands in the market: this approximation provides a better understanding to measure the type of associations of brand image with favorable or unfavorable oral answers. These answers are segmented by demographic criteria and even by evaluative answers to market attributes, as shown in the results.

(2) To increasing the strategic knowledge of the market category: through the verbal analysis of the vocabulary and the analysis of the relationships with attributes, it was possible to know the most important characteristics for consumers when referring to shopping malls.

(3) To providing an assessment of the current brand image with respect to its desired image: Keeping on mind that brand image is conceptualized as "perceptions about the brand that are reflected as existing associations in the consumer's memory" (Keller, 1993). The analyses carried out allowed knowing and estimating the image of each brand. This, at the same time, affects the positive or negative comparison of the image desired by the marketing professional.

(4) To identifying the most important and most preferred brand attributes: The analyses carried out allowed identifying the more favorable or preferred associations when referring to a shopping mall. Examples of favorable associations are "spacious", "good location", "variety of stores", and "existence of movie theaters", among others. In this case, it is very interesting to point out the associations shown between: the perception of agglomeration with SEL 6, "food court" associations with SEL 2, and "arcade" associations with SEL 3, among others. These attributes should be understood, adjusted, and articulated within the management of each shopping mall in a motivational and/or commercial program.

(5) To identifying the segments where the brand is more successful: It was possible to demonstrate, within the analyses of the brand image association typology, the capacity to articulate oral cognitive answers (favorable and unfavorable) with other important market segmentation variables. This happened with the associations women made such as: "variety of stores", "beautiful", "large" and "nice" shopping mall, as opposed to the associations made by men: "spacious", "difficult access", and "there are parking lots", 
among others. In addition, to presenting the associations that characterize each brand, as stated previously -due to the extension of this document, it is not possible to delve into that topic-. From a strategic perspective, it is recommended that each shopping mall communicates and promotes such characteristics according to the segment of the population addressed. This means, to articulate a marketing program according to the target population.

(6) To enabling managerial decisions regarding differentiation and capital investment strategies: This exploratory research on brand associations applied to shopping malls allows familiarizing with the current image in the market in order to establish shortterm and long-term strategies to differentiate shopping malls according to their favorable or unfavorable reputation. Likewise, when knowing the brand image per segment characteristics, it is possible to improve the decisions made regarding capital investment. This way, it is also possible to be more efficient when communicating the marketing of the company or of the brand. According to this, it is to be expected that the shopping mall Unicentro aims to be distinct from Andino because they share similar associative elements for the upper class. This way, Unicentro should promote its image: "variety of stores" and "spacious" counteracting its "difficult access" one. Andino can take advantage of its image: "elegant" and "prestigious" by using communication based on status. Gran Estación should strengthen and communicate its image: "large" and counteract by better managing its association to "bad distribution", "very crowded" and the perception of agglomeration. Portal 80 should reinforce its attraction commercial activity through its image: "movie theaters" and the "inexpensive" concept of its stores; and Plaza de las Américas should design a service and marketing program oriented to decrease its image: "insecurity", "congestion", "hard access", and "traffic jams". In spite of this, the research shows that its favorable image is related to the perception of "inexpensive", which is interpreted as the first attraction motivator.

Finally, the information presented here allows us to justify the implementation of a conceptual and methodological setting by providing scholars, managers, and marketing professionals with a greater strategic understanding of the market, regarding the brand associations that were validly and systematically memorized. It is important to keep into account that there are many methodologies, techniques, and instruments that are used according to the interests of each research (Cian 2011).

When talking about a potential future research, the observations of this study can become rich by including information regarding the sales of each brand and questions to evaluate the non-verbal component. Biel (1992) indicates that brand image possess a strong non-verbal component and for this reason, many brands -especially the strong ones-are commonly associated to symbols that appear mentally as soon as the brand is displayed. Likewise, we suggest organizing purchase attributes hierarchically in future studies (when referring to products tied to brands) and sample based on the characteristics of the market to which the shopping mall or brand being studied is intended. 


\section{REFERENCES}

Aaker, D.A., 1992. The value of brand equity. Journal of business strategy, 13(4), 27-32.

Aaker D.A., 1994. Gestión del valor de la marca: capitalizar el valor de la marca. Madrid: Ed. Díaz de Santos.

Aaker, D.A., 1996. Building strong brands. New York: The Free Press.

Aaker, D.A. and Keller K. L., 1990. Consumer evaluations of brand extensions. The Journal of Marketing, 54(January), 27-41.

Abascal, E. and Grande, I., 1994. Aplicaciones de Investigación Comercial. Madrid: Editorial ESIC.

Aghekyan-Simonian, M., Forsythe, S., Suk Kwon, W. and Chattaraman, V., 2012. The role of product brand image and online store image on perceived risks and online purchase intentions for apparel. Journal of Retailing and Consumer Services, 19(3), 325-331.

Anholt, S., 2007. Competitive identity: the new brand management for nations, cities and regions. Nueva York: Palgrave Macmillian.

Apaolaza, V. and Hartmann, P., 2008. Influencia de la imagen de marca, la satisfacción and los costes de cambio en la lealtad del cliente de energía doméstica. Revista Europea de Dirección and Economía de la Empresa, 18(1), 11-30.

Balmer, J., 2008. Identity based views of the corporation: Insights from corporate identity, organisational identity, social identity, visual identity, corporate brand identity and corporate image. European Journal of Marketing, 42, 879-906.

Baloglu, S. and Mccleary, K.W., 1999. A model of destination image formation. Annals of Tourism Research, 26, 868-897.

Barreto, I., Morales, A.V. and Vásquez, J.C., 2012. Estrategias metodológicas para el análisis de datos textuales: aplicaciones en psicología del consumidor. Revista Suma Psicológica, 18(2), 7-15.

Becúe, M., 1999. Análisis estadístico de textos. pp. 82-109. En Blecua, J.M, Claveria, G., and Sanchez, C., 1999. Filología e informática: nuevas tecnologías en los estudios filológicos. España: Ediciones Milenio.

Biel. L., 1992. How Brand Image Drives Brand Equity, Journal of Advertising Research, 32(6), 6-12.

Bigné, J.E., Miquel, S. and Newman, K., 1993. La imagen de los productos fabricados en España. Información Comercial Española, 722, 49-60.

Bloemer, J., Ruyter, K. and Peeters, P., 1998. Investigating drivers of bank loyalty: The comple relationship between image, service quality and satisfaction. The International Journal of Bank Marketing, 16(7), 276-286.

Chebat, J.C., Sirgy, M.J. and Grzeskowiak, S., 2010. How can shopping mall management best capture mall image? Journal of Business Research, 63(7), 735-740.

Cian, L., 2011. How to measure brand image: a reasoned review. The Marketing Review, $11(2), 165-187$

Cretu, A.E. and Brodie J.R., 2007. The influence of brand image and company reputation where manufacturers market to small firms: A customer value perspective. Industrial Marketing Management, 36(2), 230-240.

Davis, J., 2002. La Marca. Máximo Valor de su Empresa. México: Prentice Hall. 
De la Martinière, M., Damacena, C. and Hernani, M., 2008. Medición and determinantes del valor de marca en la perspectiva del consumidor. Revista contabilidad y negocios del departamento académico de ciencias administrativas. Perú, 3(6), 19-23.

Dennis, C., Marsland, D. and Cockett, T., 2000. Can a shopping centre be a "brand"? Actas del 11th International EAERCD Conference on Retail Innovation.

Diesinker, C. and Romaniuk, J., 2006. Comparing methods of brand image measurement. International Journal of Market Research, 48(6), 681-698.

Dobni, D. and Zinkham, G.M., 1990. In search of brand image a foundation analysis. $A d-$ vances in Consumer Research, 17, 100-119.

Dolnicar, S. and Grün, B., 2007. Question stability in brand image measurement: Comparing alternative answer formats and accounting for heterogeneity in descriptive models. Australasian Marketing Journal, 15(2), 26-41.

Dowling, G.R., 1986. Managing your corporate images. Industrial marketing management, 15(2), 109-115.

Driesener, C. and Romaniuk, J., 2006. Comparing methods of brand image measurement. International Journal of Market Research, 48(6), 681-698

Echtner, C. and Ritchie, J., 1991. The meaning and measurement of destination image. Journal of Tourism Studies, 2(2), 2-12.

El-Adly, M.I., 2007. Shopping malls attractiveness: a segmentation approach. International Journal of Retail \& Distribution Management, 35(11), 936-950.

Escalas, J.E., 2004. Narrative processing: Building consumer connections to brands. Journal of Consumer Psychology, 14, 168-179.

Etxeberria, J., Garcia, E., Gil, J. and Rodríguez G., 1995. Análisis de datos y textos. Madrid: Rama.

Feldman A., 2002. La integración del análisis textual a los estudios de calidad del servicio y satisfacción del cliente. Journées internationales d'Analyse statistique des Données Textuelles. Lexicometrica revue electronique. Università di Bologna, 267-273.

Finn, A. and Louviere, J.J., 1996. Shopping center image, consideration, and choice: anchor store contribution. Journal of Business Research, 35(3), 241-251.

Frasquet, M., 2000. Centros comerciales: Gestión y competitividad, Generalitat Valenciana, Valencia. Conselleria dÍndústria i Comerç.

Frasquet, M., Vallet, T. and Gil, I., 2002. Key factors in shopping centre management: evidence from Spain. The International Review of Retail, Distribution and Consumer Research, 12(4), 337-354.

García, M.J. and Bergantiños, G., 2001. Los componentes del valor de la marca: una aplicación empírica en el segmento alto del mercado automovilístico. Revista Europea de Dirección y Economía de la Empresa, 10(2), 161-178

Guerrero L, Lazzari L, and Machado E., 1999. Hacia un cambio de paradigma en la investigación de mercado. Cuadernos del Cimbage, 2, 107-129.

Hong, S., Kim, J., Jang, H. and Lee, S., 2006. The roles of categorization, affective image and constraints on destination choice: An application of the NMNL model. Tourism Management, 27, 750-761. 
Hu, H. and Jasper, C., 2006. Social cues in the store environment and their impact on store image. International Journal of Retail \& Distribution Management, 34, 25-48.

Janonis, V. and Virvilaitè, R., 2007. Brand image formation. Engineering economics, 2(52), 78-90.

Jiménez A., 2002. ¿Qué asocia el consumidor a la denominación de origen?: la imagen como factor clave en la competitividad de las empresas agroalimentarias. Revista de Desarrollo Rural y Cooperativismo Agrario, 6, 147-164.

Keller K., 1993. Conceptualizing, measuring, and managing costumer-based brand equity. Journal of Marketing, 57, 1-22.

Keller K., 2003. Strategic brand management: building, measuring and managing brand equity. 2nd edition. Upper Saddle River (NJ): Prentice Hall.

Keller, K., 2009. Building strong brands in a modern marketing communications environment. Journal of Marketing Communications, 15(2-3), 139-155.

Levy, S., 1959. Symbols by which we buy. Harvard Business Review, 37, 117-124.

Macinnis, D.J. and Price, L.L., 1987. The role of imagery in information processing: review and extensions. Journal of Consumer Research, 13, 473-491.

Martineau, P., 1958. The personality of the retail store. Harvard Business Review, 36, 4755.

Martínez Salinas, E., Montaner Gutiérrez, T., and Pina Pérez, J.M., 2004. Propuesta de una metodología. Medición de la imagen marca. Un estudio exploratorio. Esic market, (117), 199-216.

Martínez, E., Gutiérrez, T.M. and Pérez, J.M., 2005. Propuesta de medición de la imagen de marca: un análisis aplicado a las extensiones de marca. RAE: Revista Asturiana de Economía, (33), 89-112.

McGoldrick, P.J. and Thompson, M.G., 1992. Regional Shopping Centres, London: Avebury,

Moilanen, T. and Rainisto, S., 2009. How to brand nations, cities and destinations: A planning book for place branding. Nueva York: Palgrave Macmillian.

Molinillo, S., 2002. Centros comerciales de área urbana. Madrid: ESIC

Montesinos, M.A. and Currás, R., 2007. Importancia relativa de la marca and efecto país de origen sobre la intención de compra de los consumidores. XX Congreso anual de Aedem, 2, 12.

Munuera, J. and Cuestas P., 2006. Factores de atracción de los centros comerciales en España. Tendencias de la distribución comercial en el ámbito internacional, 828, 99-116

Ortegón Cortazar, L., 2012. Exploración del valor de marca y su correlación con el valor de las ventas. Revista Ciencias Estratégicas, 20(27), 105-1024

Picón, P., Varela, M., Rial, B. and Braña, T., 2013. Habi: una herramienta para la representación de la imagen de un producto o servicio. Revista Española de Investigación de Marketing ESIC, 17(1), 83-104

Pike, S., 2002. Destination image analysis: A review of 142 papers from 1973-2000. Tourism Management, 23, 541-549.

Raddar Consumer Knowledge (2013). Informe de ventas mensuales, trimestrales o anuales de los Centros Comerciales en Colombia. RADDAR CKG y ACECOLOMBIA. 
Disponible en: http://www.raddar.net/services12.html [Access November 21, 2014.]s

Robayo, O. and Ortegón Cortazar, L., 2013. Patrones de elección de marca and niveles de refuerzo diferencial en categorías de productos de consumo masivo. Psicología desde el Caribe, 30(3), 449-477

Royo Vela, M., 2006. Desarrollo de una escala para la medida de la imagen del destino cultural-rural. Colecció Diversitas. Girona: Publicacions de la Universitat de Girona. Universitat de Girona.

Royo Vela, M., 2009. Rural-cultural excursion conceptualization: A local tourism marketing management model based on tourist destination image measurement. Tourism Management, 30, 419-428.

Salciuviene, L., Lee, K. and Yu, C., 2007. The impact of brand image dimensions on brand preference. Economics and Management, 12(1), 464-471

Satriano C.R. and Moscoloni N., 2000. Importancia del Análisis Textual como Herramienta para el Análisis del Discurso. Revista Electrónica Cinta de Moebio, 9, 7-18

Schmitt, B., 2012. The consumer psychology of brands. Journal of Consumer Psychology, 22(1), 7-17.

Schmitt, B. and Simonson, A., 1997. Marketing aesthetics: The strategic management of brands, identity, and image. New York: Free Press.

Schnittka, O., Sattler, H. and Zenker, S., 2012. Advanced brand concept maps: A new approach for evaluating the favorability of brand association networks. International Journal of Research in Marketing, 29(3), 265-274.

Simms, C.D. and Trott, P., 2006. The perceptions of the BMW Mini brand: the importance of historical associations and the development of a model. Journal of Product and Brand Management, 15 (4), 228-238.

Stern, B., Zinkhan, G. and Jaju, A., 2001. Images in Marketing: Congruence of Store, Brand and Corporate Images. Marketing Theory, 1(2), 201-224.

Tapachai, N. and Waryszak, R., 2000. An examination of the role of beneficial image in tourist destination selection. Journal of Travel Research, 39, 37-44.

Valls, J.F., 1992. La Imagen de Marca de los Países. Madrid: McGraw-Hill.

Varela, J., García, A., Braña, T. and Rial, A., 2002. Imagen y posicionamiento de establecimientos minoristas. Psicothema, 14, 92-99.

Villafañe J., 1993. Imagen Positiva. Gestión Estratégica de la Imagen de las Empresas. Madrid: Ediciones Pirámide.

Winchester, M.K. and Fletcher, M., 2000. Calibrating your brand image measurement technique by utilising empirical generalisations. The Journal of Brand Management, 8(2), 99-110. 